\title{
On Strategies of Promoting International Employment for Chinese College Graduates
}

\author{
Yaozhong Lü \\ College of Foreign Languages \\ Qingdao University of Science \& Technology \\ Qingdao, China \\ simon@qust.edu.cn
}

\author{
Haixia Zhao \\ College of Electromechanical Engineering \\ Qingdao University of Science \& Technology \\ Qingdao, China \\ ammyy@126.com
}

\begin{abstract}
As higher education in China has leapfrogged into the stage of prevalence, the number of college graduates is increasing. The situation of employment is more and more serious. Making full use of the current resources to promote the employment for graduate, Chinese colleges are supposed to set up the training system for international personnel through international exchange and cooperation in education so as to promote international employment for their graduates.
\end{abstract}

Keywords—College graduates; international employment; channels; approaches

\section{INTRODUCTION}

The prevalence of higher education in China has brought about an increasing number of college graduates. With the dynamic expansion of the world economy and the transformation of the economic development in China, there exists a new trend in the college graduates' employment. As the internationalization of higher education is accelerating and foreign high-quality education resources are introduced, Chinese colleges have been training a number of talented personnel for the development of the world economy, which causes the college students' employment to be internationalized. More and more college graduates are employed in the international companies.

\section{NECESSITIES OF INTERNATIONAL EMPLOYMENT}

Enhancing the international exchange and cooperation and absorbing the foreign high-quality education resources, Chinese colleges set up the training system for international personnel. Meanwhile, they have constructed the platform for international employment and create employment for students in international enterprises.

\section{A. International employment is an effective means to expanding employment opportunities}

Realizing the current situation of employment, the Chinese government takes employment as a priority of economic and social development. With the continuous expansion of enrollment in colleges, there are an increasing number of graduates in China, covering 6.99 million in 2013, 7.27 million in 2014, 7.49 million in 2015, 7.65 million in 2016, 7.95 million in 2017, which puts heavy pressure on employment. At present, gaining employment for graduates is a big issue.

To promote employment of college graduates, the State Council requires local governments to create more opportunities of employment in different ways, further improving the relevant policies and measures and strengthening the employment service. In this context, international employment is a new channel to expand the employment opportunities for college graduates, which can ease employment pressure.

\section{B. International employment is the requirement of the internationalization of higher education}

With the development of economic globalization, internationalization of higher education becomes the inevitable trend, which puts Chinese colleges into the broader international space. It requires them to strengthen the international exchange and cooperation in the fields of teaching, scientific research and personnel training. To make full use of the foreign high-quality education resources, Chinese colleges need to educate the internationalized personnel with international awareness, international communication ability and international competition ability.

The employment of college graduates reflects the quality of the students' training. Introducing and utilizing the foreign highquality education resources, Chinese colleges are setting up a training system for internationalized personnel. In the process of training the internationalized personnel, they strengthen the international exchange and cooperation and actively build an

This paper was sponsored by the Teaching Reform Research Project for Provincial Universities in Shandong (NO. 2015D004) and Shandong education Science Planning Project (No. ZC15110) 
innovation platform to broaden the students' international vision. By improving their international employment ability, students find a popular way to boost new job opportunities.

\section{International employment is needed in world economic development}

Along with the rapid development of science and technology, most countries have greatly improved production efficiency. Reducing production costs has become an important option to further develop the national economy. The United States and other developed countries are gradually turning to the knowledge-based economy from a manufacturing economy. Therefore, more highly-skilled innovative personnel are needed. Accompanied by the emergence of service economy employment in the service industry is on the rise, and more technical personnel are needed in financial enterprises, social welfare, medical services and other related information technology fields.

Nowadays, the development of information technology and microelectronics technology is constantly creating more opportunities of employment, which requires new employees to have professional knowledge in engineering science and the corresponding qualities. Rapid economic growth causes the developed countries such as the United States, Japan, the United Kingdom, Germany, and France to require a large number of scientific and technological personnel, especially in high-tech areas. This need provides a new opportunity of international employment for college graduates.

As China is transforming its economic development mode and adjusting the economic structure, more and more foreign companies are entering the Chinese domestic market and require a large number of international talented personnel to expand the market. The demand for international personnel has been increasing. To a certain extent, it has promoted the internationalization of employment for college graduates.

\section{CHANNELS TO IMPROVING COLLEGE STUDENTS' ABILITIES FOR INTERNATIONAL EMPLOYMENT}

With the acceleration of the internationalization of higher education, the trend in teaching, scientific research and students training are becoming increasingly internationalized in Chinese colleges. By introducing foreign high-quality education resources and using the international platform to improve capacity for scientific research capacity and commercialization of achievements, the Chinese colleges promote the internationalization of the students' employment.

\section{A. Utilizing foreign high-quality education resources to develop the students' abilities for international employment}

In recent years Chinese colleges have actively implemented the supporting policies stipulated by the Central Government to strengthen cooperation with colleges and universities of the developed countries and to introduce their advanced education paradigms, teaching methods and teaching materials. This optimizes the Chinese education course system by improving teaching methods and for cultivating international innovative personnel.

Through joint education programs, Chinese colleges introduce advanced courses and teaching materials, learning from foreign education institutions and absorbing their successful management experience; this improves China's domestic teaching and management. Meanwhile, Chinese colleges are using the international mutual recognition of qualifications to improve the flow of talents and leapfrog development of the internationalization of personnel training.

Strengthening cooperation with the top universities of foreign countries, Chinese colleges should implement international cooperative education and enhance the international competitive ability of students. By combining the school environment with international enterprises, international cooperative education properly arranges course learning and social practice. It builds the students' training scheme, teaching contents and practice more closely to the needs of the development of the international community. It also promotes the students' practical skills to enter the international labor market.

\section{B. Establishing the training system for internationalized personnel to improve the employment ability of college students}

With the social and economic development, great changes have taken place in the qualifications required by new employees. A qualified worker is supposed to provide a useful service to society. More than basic skills, he or she must achieve an overall high quality standard. Specifically, they should have employable skills to meet the needs of international corporations and enterprises.

Chinese colleges must set up the training system for internationalized personnel according to their own characteristics. The training for international personnel needs to have teachers with the international vision. Colleges should develop internationalized faculty, sending young teachers as visiting scholars to the well-known universities and research institutes in the developed countries and expanding the teachers' perspective of international education.

The content of global understanding should be increased in the lectures, and the curriculum enhanced with the knowledge of international business and world culture. Students should learn to improve their intercultural communication competence.

\section{Developing the overseas internship programs and training students' ability of international employment}

An overseas internship program offers a student, especially a senior student, opportunities to work as an intern but also improves their ability for international employment. Zhao Wei, the president of Macau University, said, "overseas internship is a two-way interview; a student works in the company for months, familiar with the working environment, its culture, management and the future development direction and then they can decide whether to stay at work in the company, in turn, the company also can know the student's quality, his or her knowledge and ability." 


\section{APPROACHES TO PROMOTE INTERNATIONAL EMPLOYMENT FOR COLLEGE STUDENTS}

Currently, employment for Chinese college graduates is difficult. With the rapid development of higher education around the world, employment of college graduates has become a global issue. Many countries take measures to promote college students' employment. Chinese colleges should change the concept of education and make full use of existing resources to promote graduate employment, to develop college-enterprise cooperation and to construct the platform for practicing international employment.

\section{A. Changing the concept of education and cultivating internationalization awareness}

Along with the development of economic globalization, more and more international companies enter the Chinese market to develop their business. They require personnel with international vision and competitiveness, which requires colleges to adjust the training system for the students.

The training of international personnel requires teachers with international vision where the traditional concept of teacher education cannot meet the requirements of international education. Through the introduction of foreign high-quality education resources, Chinese colleges should carry on the reform in the paradigms of teaching, education management, course systems, teaching evaluation and examination system to raise students' awareness of the globalization so as to meet the requirements for international personnel to adapt to social development.

In addition to training international personnel, Chinese colleges should build a concept of international employment and promote the internationalization of student employment, based on the existing employment guidance system. The idea of international employment is introduced in the employment guidance course and gives students a concept of international employment. The students should take advantage of the training system and set up their own awareness of internationalization. Through the internship platform and college-enterprise cooperation, students are encouraged to form the idea of international employment and to improve their own international employability.

\section{B. Developing college-enterprise cooperation for training the students' employment ability}

Through the cooperation with enterprises, colleges should train their students according to the enterprises' needs and allow them to be employed in the international enterprises so as to realize the connection of personnel training with social demand. The colleges can open up a channel to promote the international employment for the graduates by developing after-bachelor's program in the international enterprises, which will work together to train the international personnel. The college-enterprise cooperation will provide a more convenient channel and more opportunities for graduates' employment.

The college-enterprise cooperation for training students can make the students to realize international employment. Through the training mode of "learning- practice-learning - practice", the students keep learning and improving their practical ability. They are supposed to practice and train in an enterprise after completing a course at school. Step by step they will possess professional knowledge and have ability to do team work and innovation, which are the requirements for the international personnel.

\section{Constructing the internship platform for international employment and enhancing the effectiveness of career guidance}

The training of international personnel should be based on the needs of international enterprises. Colleges are supposed to examine the quality of graduates' skills and have full understanding of the requirements of enterprises for international personnel, before they optimize the personnel training system according to the enterprise's feedback. Through constructing a platform for international cooperation, colleges can improve the cultivation of high quality of international personnel and raise the students' level of competitiveness for international employment.

Meanwhile, Chinese colleges should develop more joint education programs with foreign colleges and provide more opportunities for students to study abroad, improving their international perspective and enhancing the graduates' ability for international employment.

The government, enterprises and colleges should work together to construct an internship platform for international employment and improve the international employment ability of students. Internship is a transition from school into the society for the students and is also an effective way to enhance their employment ability.

The governments should make relevant policies to support the overseas internship. For example, foreign enterprises in China are entitled to enjoy tax preferential policies if they accept students as interns. The Chinese colleges should actively set up overseas internship bases that meet the students' needs so as to expand international employment for students. Overseas internship programs can enhance students' ability for overseas practice and employment. They open up a new channel for students' international employment. 


\section{REFERENCES}

[1] Wang Yongquan, "On internationalization of education,” Journal of Qinghai Minzu College (Social Science Edition), vol. 1, pp. 111-113, January 2004.

[2] Bi Xiaoyu and Zhang Xiaoming, "Introverted and extroverted: analysis of development patterns of Sino-US higher education internationalization," Modern University Education, vol. 1, pp. 84-88, January 2006.

[3] Gu Jinglei, "International comparison of college students' employment policy", Comparative Economic and Social Systems, vol. 1, pp. 179-182, January 2010.

[4] .Liu Siyang, "International comparison and reference of Chinese college students' employment," Hebei Finance, vol. 6, pp. 64-66, June 2010.

[5] Liang Shuqing and Li Lei, "On ideological and political work in training system of international personnel", Journal of Hebei Radio \& TV University, vol. 3, pp. 92-94, March 2011. 